\title{
Krimulda Church and the cultural and historical environment around it
}

\author{
Jānis Zilgalvis, Dr. arch., a full member of the Latvian Academy of Sciences
}

\begin{abstract}
Krimulda Lutheran Church is located at Krimulda Parish of Riga Region. Together with the rectory building, the place of worship is included in the list of the State protected cultural monuments. Over time, the cultural and historical environment consisting of historical evidence archaeological sites, landscape elements, etc.. In the vicinity of the church has little changed, the spatial structure of planning is also retained. With regard to today's activities, it must be ensured that the environmental quality is not compromised. That's why its research remains topical and necessary in the broad neighborhood context.

Keywords: protection and preservation of the architectural and cultural heritage, landscape architecture,
\end{abstract} protection of the cultural and historical environment

\section{Introduction}

Churches are one of the most typical components of the Latvian rural architecture and landscape. Over time, many buildings of this typological group have been destroyed, demolished and have collapsed. Despite the fate, other ones have reborn and serve the needs of the modern society. The nearest and distant cultural and historical environment of this place of worship consists of a range of historical, architectural, and archaeological evidence. Each of them has its own meaning and connection to the church, including the parsonage building which consisted of not only the pastorate but also of other buildings such as the servant house, stable, cattle-shed. A specific role in the creation of the expressiveness of the ensemble was also played by the landscape and natural elements - the terrain, road network, separate plantations, and their arrays. This applies to Krimulda Lutheran Church the surroundings of which are particularly rich in cultural and historical evidence. A large proportion of them is a story of the survival and their cultural space has kept its authenticity. It is a value which must be protected and defended of thoughtless formations or works. Therefore, the need was urgent to focus on the research of the ancient place of worship in a broader environmental context.

\section{The history of construction of the church}

Krimulda (Kremon) Church is now the oldest, recognized as serving to its task church in Latvia. The building was built from 1205 until 1206 from boulders and dolomite, its oldest part, attributable to the $13^{\text {th }}$ century, is the altar part. It is covered with a dome-shaped arching divided into eight sectors. Originally, the rib bricks were rough and contrasted with the white vaulted sails. Over time, the ribs and vaults were covered with lime mortar and during the repairs of 1902-1905 with a thick cement mortar that changed their subtlety. The sacristy adjoins the

northern wall of the altar room where there are two rooms. The sacristy was built simultaneously with the altar room and it is already mentioned in the documents of 1207 . At the end of the $19^{\text {th }}$ century, its was extended. The church has one nave, the congregation room is covered with a barrel vault, from the altar part it is separated by a wide triumphal arch. The long life of the church is full of events. Originally, it was called Kubesele Church and it was built under the leadership of Priest Alebrant (Alobrandt), soon after returning of Caupo from his trip to Germany and Rome. The name of Kaupo is mentioned in the Chronicle of Henry of Livonia in 1200 and he was called the Liv King of Turaida (Treyden) Municipality [1]. It is possible that his ashes (he was killed in the battle of 1217) were buried in the altar part of Krimulda Church.

In 1630 , the church had no rafters and the roof, and only the ridge was covered with straw. Around 1640, the Riga builder Jirgen Horn (J. Horn) restored the church. In the audit documents of 1643 , it is found that the church is ready, just without having the ceiling - so the restoration works continued to be sluggish. In 1669, it is mentioned that the church is still without the ceiling and the bell is hanging on scaffolding erected on the hill. In 1699, the builder and carpenter Henrich Vede (H. Vede) built a baroque tower, installed a roof, made windows. The indoor spaces were also fitted out. In 1701, the openings were widened. In the same year, the Riga master Lars Nilson Spaak (L. N. Spaak) corrected the church walls, built three pediments with fachwerk, a number of low and narrow window openings were made wider and higher [2]. In the subsequent years, repair works were carried out several times. The church is depicted in the drawing made in 1794 by J. Ch. Brotze (J. Ch. Brotze) [3]. It shows a little 


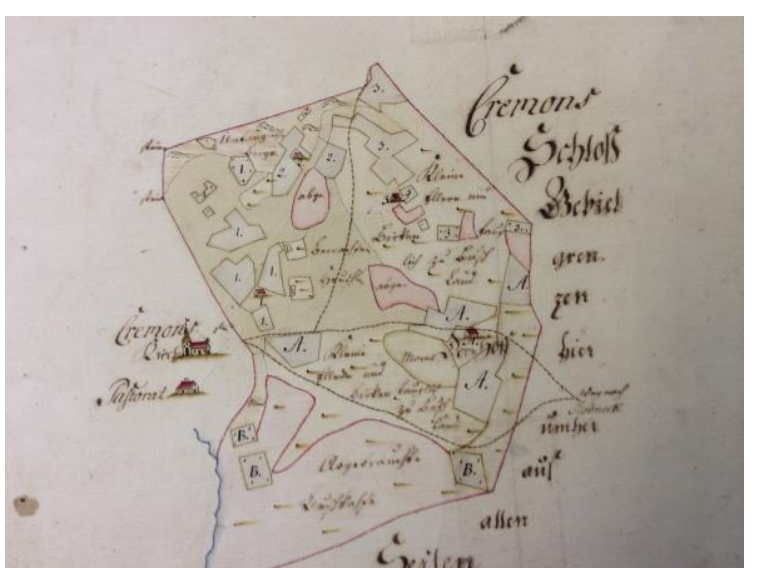

Fig. 1. Krimulda Municipality and Ķizbele Manor with peasant farmsteads [Source: Latvian State Historical Archives, 7404.f., descr. 1, p.146]

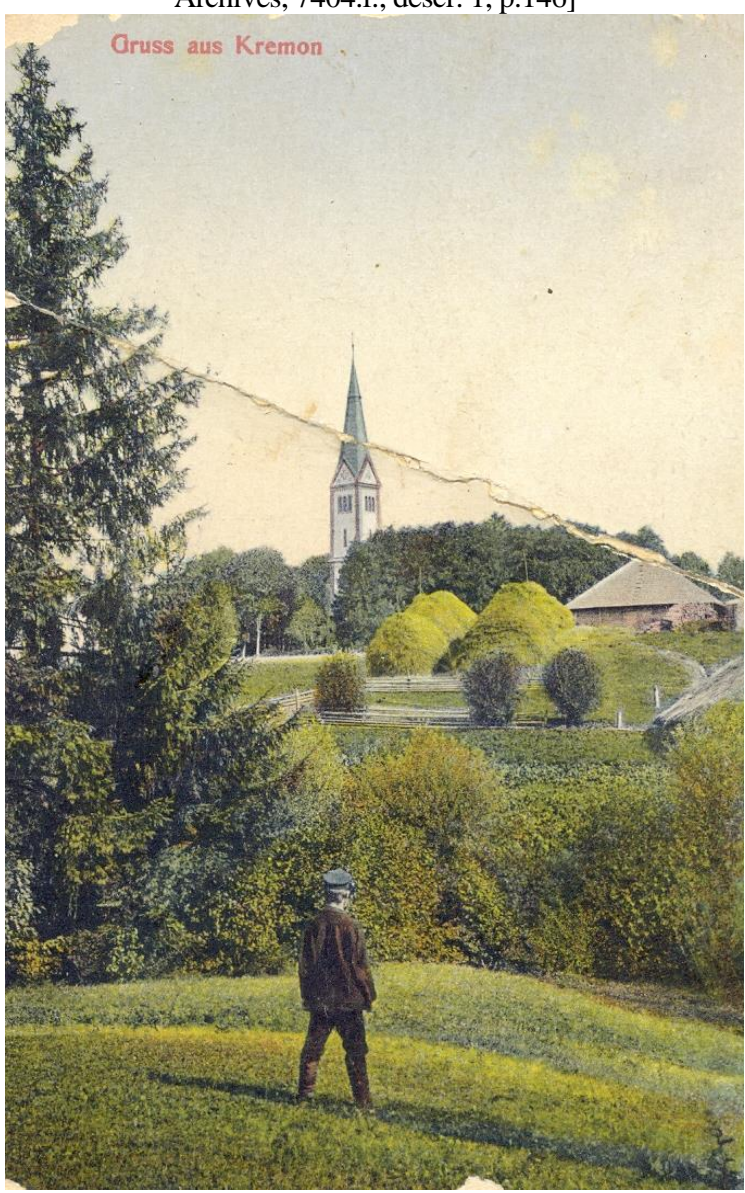

Fig. 2. The landscape of Krimulda Church

[Source: State Inspection for Heritage Protection of the Republic of Latvia, Monument Documentation Center, the 1900s]

stone church with the altar end and the sacristy extension. Above the roof ridge, there is a small polygonal turret with a baroque spire crowned by a ball with a cock. The main entrance of the church is accentuated by a perspective portal in the late Romanesque forms. On both sides of it, niches with the same semi-circular lintel are visible. On each side, the congregation room is illuminated by three windows but the chimney rises above the sacristy. In that year, the second drawing was made by
J. Ch. Brotze where the church is visible from the other side [4]. From it, we get to know that a small extension with an entrance and the side load of the cover were provided by two buttresses. Both drawings by J. Ch. Brotze were made at a time when Pastor Karl Emmanuel Pegau (K. E. Pegau) served at the congregation. In 1816, he was changed by Pastor Karl Christian Ulmann (K. Ch. Ulmann) who later became a professor of the University of Tērbata and from 1840 until 1841 he was its rector.

In 1865, thorough repairs of the church were made - the pulpit was moved in another place (the current one), the triumphal arch was significantly widened, a new plaster ceiling was installed, benches and doors, new floors were partially installed, the walls were painted, etc.. There was a basement below the church which was completely walled up. In 1898, the dressing chamber was expanded by rebuilding the chamber into space for children to be baptized and newlyweds. The following year the repairs of the church were made - the altar room was painted, the old glass of the windows was replaced by new stained-glass windows made by Ernst Tode (E. Tode,1858-1932) in his workshop in Riga. The works were financially supported by the owners of Bīrini (Koltzen) and Sējas (Zögenhof) Manors, as well as by the Latvian church members. Already in 1899, it was decided to build a new church tower. In 1902, the foundation was laid and it was finished in 1905. The construction works were led by the construction master from Sigulda - Jēkabs Ozols. The tower project was developed by the architect August Reinberg (A. Reinberg, 1860-1908). In architecture, the formal direction of the eclectic style dominated - the so-called brick style. On the background of the lightly tinted walls, elements formed in the brick- lay pattern were highlighted - eaves, arcades, window isle borders. The first floor of the tower with the prospective portal and the stairway extension on one side was built entirely of bricks. In order to architecturally link the new tower with the historical volume, small ornamental corner turrets and a rhomboidal belt below the sides of the pediment were created the same as on the tower and the stairway extension facades.

The church greatly suffered in 1917 and 1918, the tower was gunshot, the window panes were broken, almost all of the old historic church equipment items were dragged out. Only the big silver bowl (1768) and the small altar hanging were left over. In 1920, the church was brought in proper order. In 1929, on behalf of the Board of monuments, the architect Pēteris Ārends studied the church, carried out photo fixation and measurements. He has also described art items, such as the altar hanging of dark red velvet with 


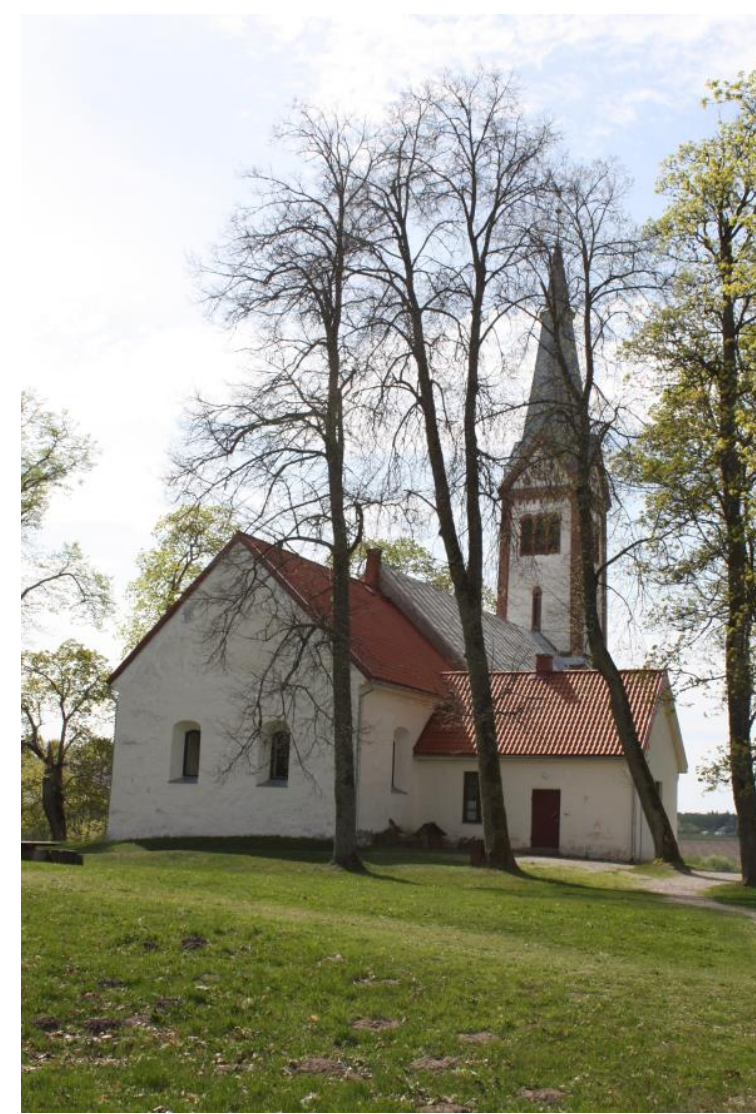

Fig. 3. Krimulda Lutheran Church [Source: photo by author, 2016]

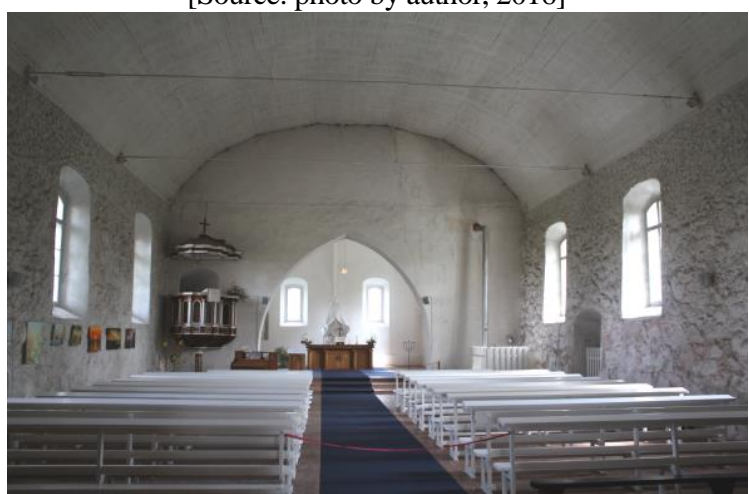

Fig. 4. Krimulda Lutheran Church

[Source: photo by author, 2016]

a white silk lining, with golden fringes. In the middle, a cross sewn in gold, around it ivy and laurel leaf garlands are sewn on from lighter greenish yellow velvet. On the other side, under the lining - "Catharina von Dahl, geb. von Wilcken. Engelhardshoff, den 25 sten Mai 1867."

\section{The fate of the church during the Soviet times and later}

During World War II, the church did not suffer. In 1949, a list of the items of the cult was drawn up. It included two electric chandeliers, two baptismal fonts, the collection plate, four candelabras with multiple arms, two candlesticks with one candle, three tablecloths, a flower vase, carpets, wooden boards with numbers, two old wooden tables, six old damaged chairs, worn velvet runners, an old hearse, an old metal goblet, a dish, an old Bible, song books, a carafe, a glass and a tray [5].

In 1953, a list of the architectural inventory is drawn up. The above mentioned wooden loft, the altar with a crucifix, the old altar with three paintings (1724 and 1865), the pulpit with the caret,13 parishioner benches, a damaged pipe organ and a steel bell [6]. During this year, the survey of the building's architectural and constructive elements is also carried out. It is mentioned that the technical condition is satisfactory, the floor - of the red brick screed, the boards are painted in the congregation room, the walls are plastered but damaged in the dressing chamber and the congregation room from leaking of the roof left not repaired, the vault of the altar part is painted in the shades of pink, in some places the plaster has fallen from the cylindrical vault of the congregation room due to the damaged roof, the windows are glazed, only one is broken in the tower entrance, the organ is damaged, the old altar has three oil paintings [7]. As a result of the survey, the above-mentioned drawbacks are demanded to be eliminated.

In 1960, in the result of the pressure from the Soviets power, the church was closed and the congregation was liquidated. The tribulation time started. In 1966, the remaining parts of the pipe organs were collected from Birži (Buschhof), Vārkava (Warkau) and also from Krimulda, and stored in Jēkabpils. By the initiative and support of the District Party Committee and the District Executive Committee, it was decided to build-in a concert organ on the balcony of Oškalna Culture House in Jēkabpils, using the above-mentioned remaining parts and parts of pipe organs from other congregations. But it was not enough for the remaining parts and the cultural activists of Jēkabpils District turned to the Ministry of Culture to get permission to get the pipe organ of Lielstraupe Church being in a quite good condition.

The congregation was renewed at the end of 1988. The revival of the place of worship was initiated by Kaspars Dimiters who presided over the congregation. In 1996, the building was already under the roof, the indoor space was fitted out, benched were bought, later the pulpit was restored [8]. In 1991, during the repair works of the church, the archaeological monitoring was carried out (archaeologist Jānis Ciglis). Before installing a new brick screed, it was necessary to study the breached and vandalized stairway located in the altar part of the church. One crypt with two burials was studied where two adults and one child were buried. The burials date back to the $17^{\text {th }}, 18^{\text {th }}$ centuries. It should be noted that until the autumn of 1990, the church was in the balance sheet of Gauja National Park. It was held in control of the above park in 1978 as an orphan site and it was the initiative of the 
administration of Gauja National Park. Before, the scientific and research farm "Krimulda" had to take care of the building but nothing was done. In 1992, the repair works of the congregation room of the church were carried out. It had no floor, no windows, the exposed walls helplessly stared towards you and the places of the beam ends evidenced of the former existence of the loft. In 1994, a Catholic congregation was founded in Krimulda and the Lutherans had to conclude a contract with the newly founded congregation of the property sharing.

\section{The church equipment and the interior}

Also, each of the church equipment items has its own story. The old altar appears several times in the photos of A. Birznieks taken in 1920. In its center, the altarpiece "Christ on the Cross" was placed, at the bottom of the altar - in the predella - The Last Supper representation but at the top, the baptismal of Jesus was displayed. The architectural part of the retable consisted of two round freely standing columns on podiums which were supported by a richly profiled eave. The two edges were decorated by strands of acanthus leaves. Above the eave supporting the columns, ball-like decors were placed and the same was also on the top of the retable. These elements were also raised on podiums. The altar was made in 1724 and restored in 1865. It was the given as a gift by the owners of Grāve (Gravenhof) Manor. The pulpit is the evidence of the Baroque time (the first half of the $18^{\text {th }}$ century,). Its body is polygonal, it is surrounded by richly profiled eaves - one along the top, two at the bottom. In each plane of the body, 11 painted blocks were built in. Their shape is rectangular, with a profiled semi-circle top. Round columns are placed in the facets of the body that support the projection of the upper eave. The built-in panels of the pulpit depict the Apostles and Jesus Christ to his full height. In general, the brownish and grayish tones dominate in the paintings. The images of the Apostles are painted in brighter colors. For instance, St. Paul, who is leaning on his sword, St. Peter with keys and an open book in his hands, etc.. In the Soviet times, when the church equipment was destroyed, fragments of the pulpit were delivered to the museum of Rundāle Palace. In 1995, the congregation had an intention to get the above mentioned back from the museum and to reconstruct the pulpit, eight paintings had survived in good condition. This work was accomplished in 1996 and the pulpit began to serve the purpose. The body and the roof were made anew as copies because they were in poor technical condition but the paintings have returned to their places.
The new altar, which was installed in 1870 , was formed by a crucifix placed on the mensa. As a copy of the sculpture made by the Danish sculptor Bertel Thorvaldsen (B. Thorvaldsen, 1770-1844), it was made by his student Johann Nepomuk Zwerger (J. N. Zwerger, 1796-1869). The crucifix was given as a gift by the owner of Bīriņi Manor - August von Pistohlkors (A. von Pistohlkors, 1822-1886). It perished in the 1960s. In 1996, several sculptures were made - Our Lady, Saint Francis of Assisi and Thinker which were placed in the church. In the altar part, behind the mensa, the sculpture Christ Invites (1996, sculptor Grair Avertyan) was placed. The oak altar table, covered with a granite slab, was installed in 2004 (the interior decorator Maija Avota).

In 1823, the organ was made by Johann Christoph Kristin of Katlakalns. Later, it was sold as unuseful to Jerrkuli School but in 1910 a new organ was built by the firm of Emil Martin (1848-1922) which in 1917 was demolished. In 1926, a new organ made by the Riga organ construction firm $\mathrm{H}$. Kolbe and J. Dūrējs was consecrated. Its fate is already mentioned above.

The old church bell was cast in 1635 , in Stockholm but in 1977 it was broken and in 1878 was recast by J. Schwenn. In 1895, a new bell was consecrated, making of which was funded by both congregations of Krimulda - the German and Latvian ones. It was made in Germany, Bochum. During World War I, by the Government order, the bell was evacuated to Nižnijinovgorod in Russia and back into 1922 [9].

Until World War II, in the altar room above the door that leads to the pastor's room a black stone plaque was affixed with the inscription - Anno 1205 im 8 ten Jahre des 3 ten Rigischen Bischofs Albert Buxhoweden zu Apeldern ist hier zu Cubbesele bey der Burg des Livischen aeltesten Caupo diese kirche, nachmahls Kremon genant vom priester Alobrandt erbaut worden ...

\section{The rectory}

The rectory is located in the immediate vicinity of the church. The rectory is a distinctive sample of the wooden architecture of the Classicism period. According to the information available by the priest Jānis Ërmanis (1862-1932), it could be built by the initiative of the owner of Krimulda Manor - von Helmersen in 1775 [10]. The building is a log house with a steeped pitched roof, the ends of which are partially oblique. Two porches can be seen in one longitudinal facade near the entrance, in the other one a portico was located. Originally, there was only one porch - verandah on the right side [11]. The construction form of the building is traditional, gently rounded, rather unwieldy. The old classical door sashes were valuable monuments of art (the first half of the 19th century) which have now 


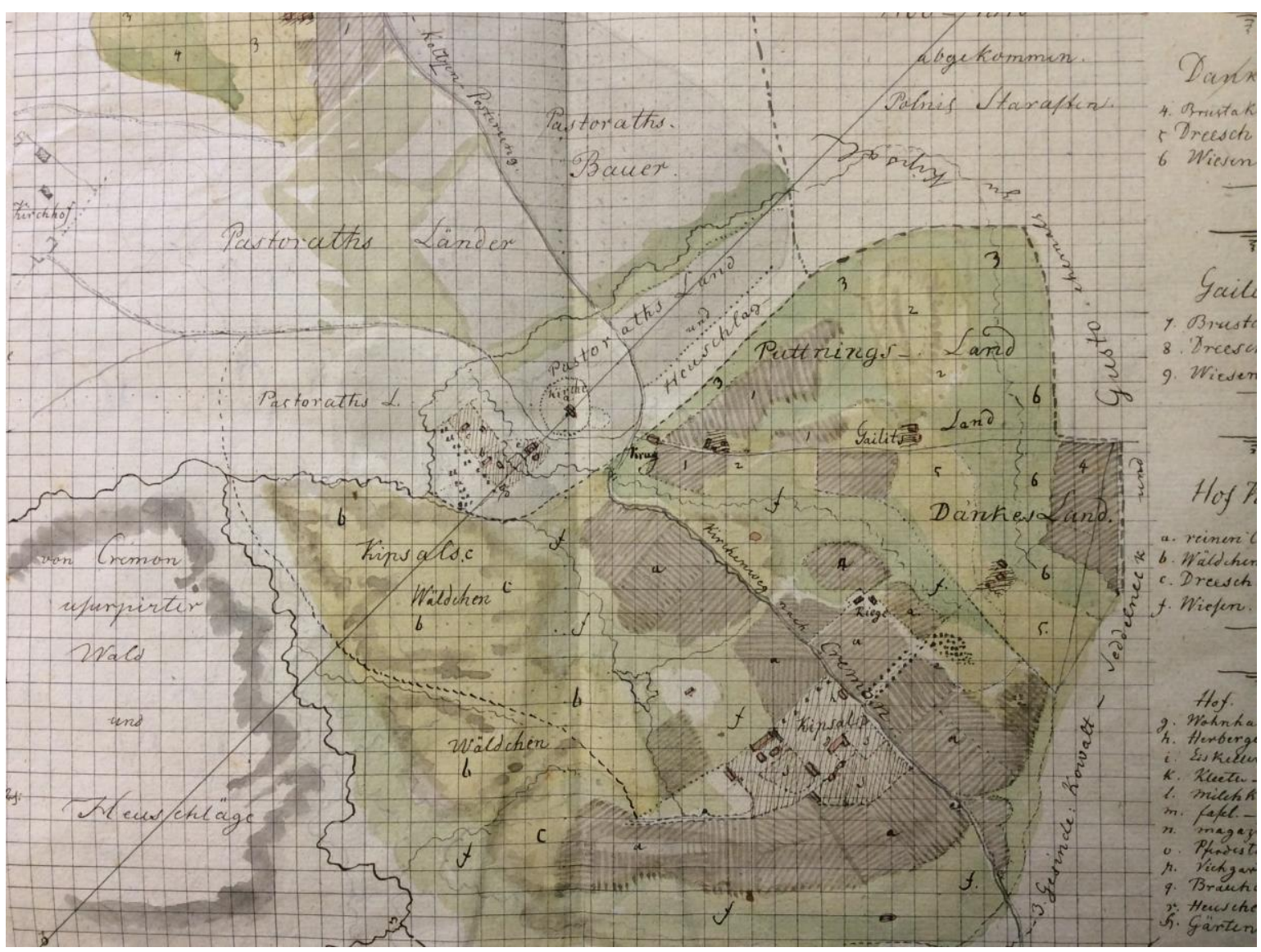

Fig. 5. Kizbele Manor and the layout of the parsonage situation. 1821. A drawing by J. V. Krause

[Source: Latvian State Historical Archives, 6828.f., descr. 6, p. 4430]

been replaced by new, similar ones. In 1980, thanks to the activities of Kaspars Dimiters, the pastorate experienced a revival. In 1912, the pastor J. Ërmanis opened a library there with 262 volumes. Through offering valuable books, its purpose was to combat corn trashy books. The library was devastated in 1917. In the context of the Krimulda congregation, Cross School Book written by the local teacher Juris Natanaēls Ramanis (1797) should be mentioned - a collection of various essays, the rebellious nature of which led to a conflict with the pastor [12]. A memorial stone set up in 1993 at the roadside opposite the church was devoted to him (the sculptor Vilnis Titāns). The servant (ringer's) house is located near the pastorate, the pediment of which is created in the fachwerk construction.

The rectory building together with the church formed the scenic and planning structure of the surrounding area. It can be made sure by examining the situation plan drawn by J. V. Krause in 1821 , where every building, road, forest and the fields, the more distant cemetery are detailed [13]. It can be seen that the present road from Turaida to Ragana directly approached the church, not passing by, as it is now. Walking across the brook, it as if encircles the church and further winds along its present location. The places of peasant farmsteads can be also seen in the plan, such as Puttning,
Wegge, Gailit, Danke. Some of these place names have survived to our days, such as Putnini and Vegi. According to the plan, it can be learned that there was a barn, out-house, horse stable, and cattle-shed in the parsonage. In turn, the building of Kizbele (Kipsal) Manor consisted of the landlord's house, out-house, ice cellar, granary, milk chamber, storehouse, horse stable, cattle-yard, brewery, barn, and garden. It should be noted that the situation layout is not drawn by a land surveyor, so it is rough but a significant cultural and historical reference.

On the situation around the church can be also judged by the land plan of the Krimulda parsonage which in 1862 was drawn by the chivalry auditor J. E. Wruck [14]. Closer to the church, there are four small buildings, behind them - the rectory buildings, one of them - the dwelling house in the present place. Downstream of the personage, at the foothill a school is marked which in the plan of 1821 is not shown. In the lower part, the parsonage land borders with the Gauja, in the lower part on right the boundary goes along a brook behind which the land of Kizbele Manor is located. On the left, the land borders with the fields of Krimulda Manor and higher - with the fields of the Rodi (Rohde) home. 


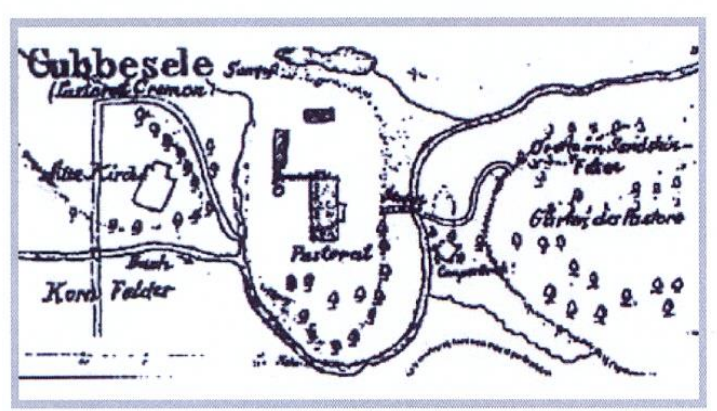

Fig. 6. Kubesele Church and the rectory in the $17^{\text {th }}$ century [Source: htpp://renatar.livejournal.com/254924.html]

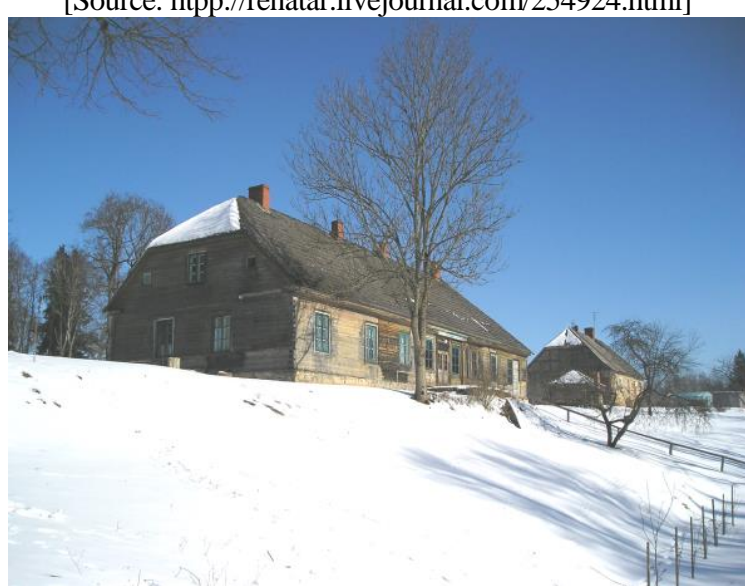

Fig. 7. The Krimulda pastorate [Source: photo by author, 2010]

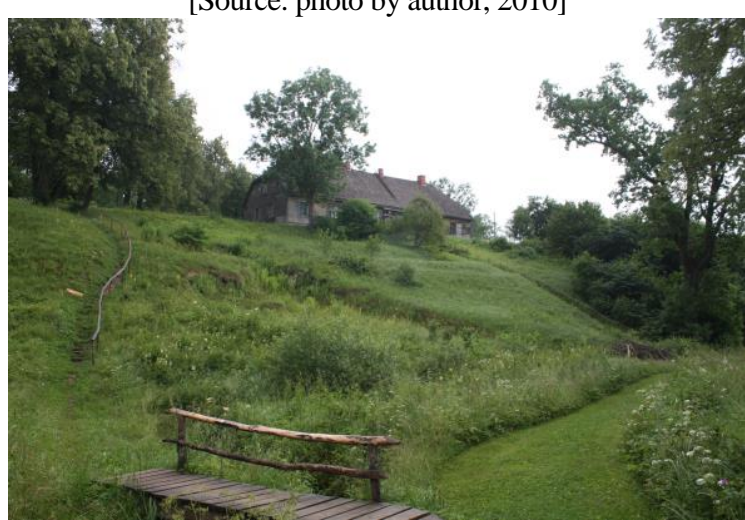

Fig. 8. The Krimulda pastorate

[Source: photo by author, 2016]

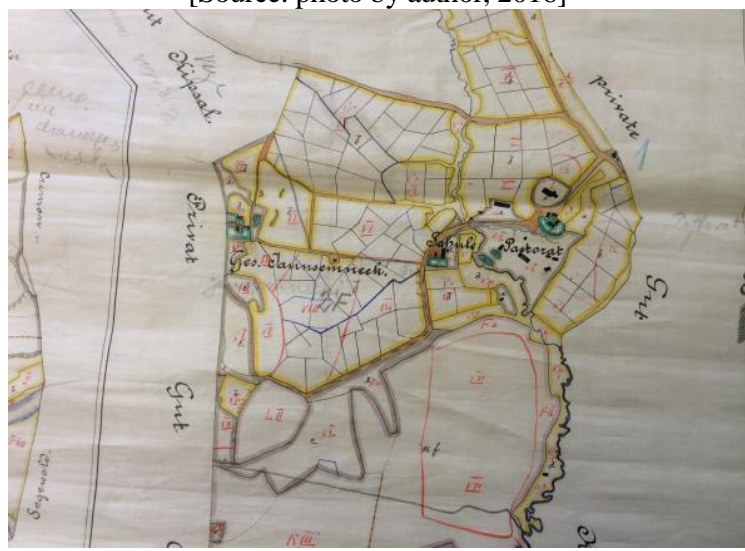

Fig. 9. The land plan of the Krimulda rectory, 1862 [Source: Latvian State Historical Archives, 1679.f., descry. 194., p. 86]

\section{Historical and archaeological evidence}

There is a great diversity of the cultural and historical environment in the immediate vicinity of the church. It includes the historical and archaeological evidence, the landscape, and natural elements. The $3.6 \mathrm{~km}$ long nature trail of Kubesele, created in 2002, starts near the pastorate. The trail, which is a broad and versatile reference leads up to the Gauja and on the way back ends in its starting point. Walking along this trail, we can get acquainted with a series of monuments - Kubesele Castle Mound where in 1991 the early Iron Age items were found during the archaeological research, the commemorative site of Caupo which is marked with a memorial stone on which there is a quote from the Chronicle of Henry (2001, sculptor G. Grundberga). In one section of the road, it is possible to get acquainted with the Barons' cemetery which is located in a special compartment of the old cemetery, created in 1820 . The family tomb of K. von Dahl, the owner of Englārte or Engelhārte (Engelhardshof) Manor was located there, as well as the mortuary of Duke Dunten. During World War I, the latter was devastated and has not survived to our days. In the so-called Landlords' Cemetery, pastors and their relatives were also buried. Today, two gate poles built anew in 1928 instead of the old ones lead to the cemetery which is overgrown. Information about the history of the ancient times is provided by Batarini Mound Cemetery where the so-called Semigallians of the Gauja - the Balt tribal representatives were buried. The burials refer to the time from the $1^{\text {st }}$ millennium before the birth of Christ until the first centuries of our era. They are described in the publications of the end of the 19th century [15].

In the cemetery, on one large mound, a whole family was buried in the course of time, unlike the Liv mound cemeteries where on each one only one person was buried. On the way back, opposite the pastorate on the hill, the cave of Kubesele can be seen, also called Runtinala /the cave of Runtina/. It resembles a big space that is around $6 \mathrm{~m}$ long, but its height is about $3 \mathrm{~m}$. The cave, which is a protected geological site, was formed as a result of continuous movement of the underground waters in the Upper- Devonian sandstone of the Gauja retinue. The above historical, natural, and archaeological evidence enrich the cultural and historical environment of the nearby church, reflect the developments over centuries, formed in the interaction of the human and natural environment. Each of the sites should be specially protected and cared for, their neighborhood or the cultural space should be respected without which the perception of the historical evidence wouldn't be possible. 


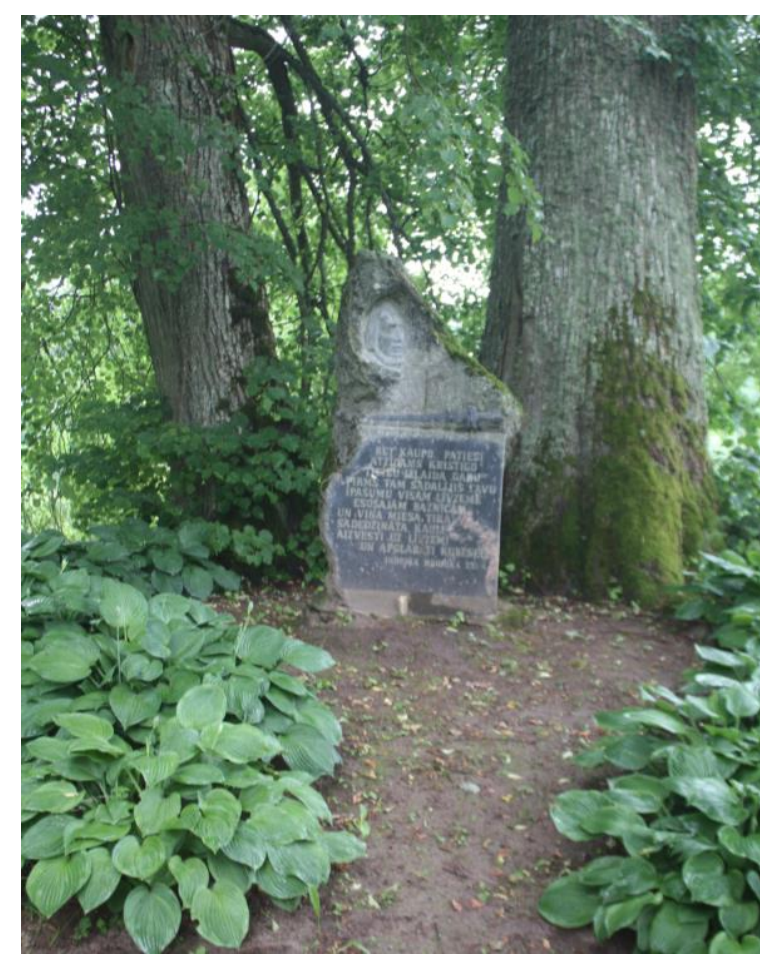

Fig. 10. Monument to Caupo

[Source: photo by author, 2016]

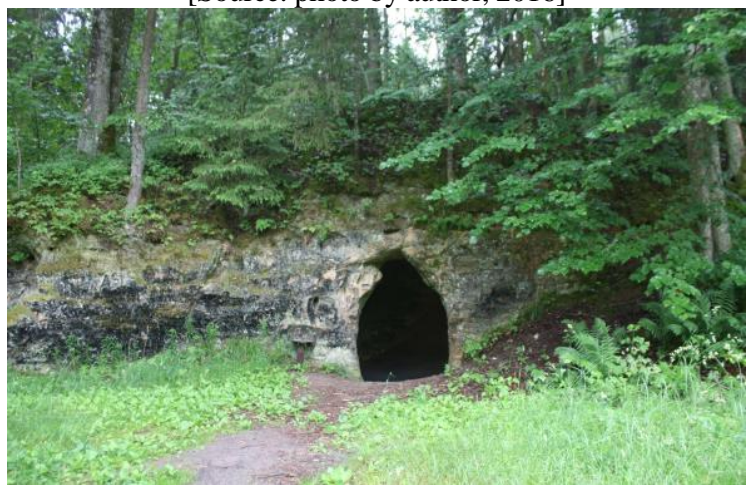

Fig. 11. Cave of Kubesele

[Source: photo by author, 2016]

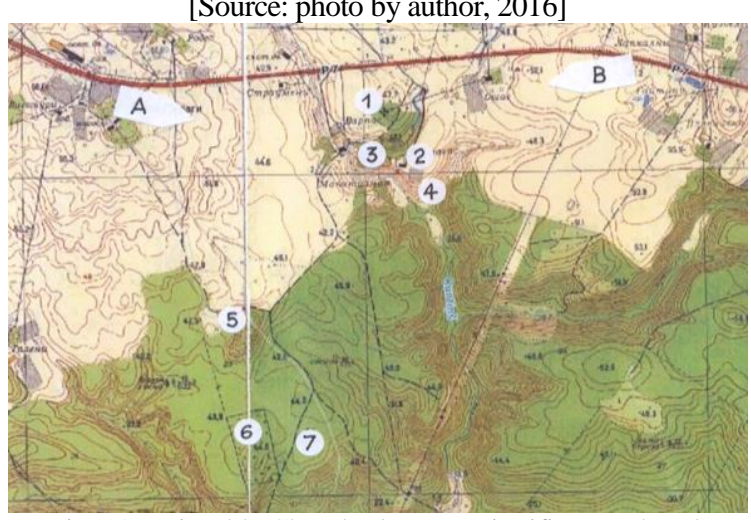

Fig. 12. Krimulda Church: the most significant cultural, historic, and scenic area around it [Source: drawing by author in the topographical plan of 1967]; 1 - church;

2 - rectory; 3 - Kubesele Castle Mound; 4 - Cave of

Kubesele; 5 - Landlords' Cemetery; 6 - cemetery;

7 - archeological site; A, B - the main sight points to the church in the landscape from the road Ragana - Turaida

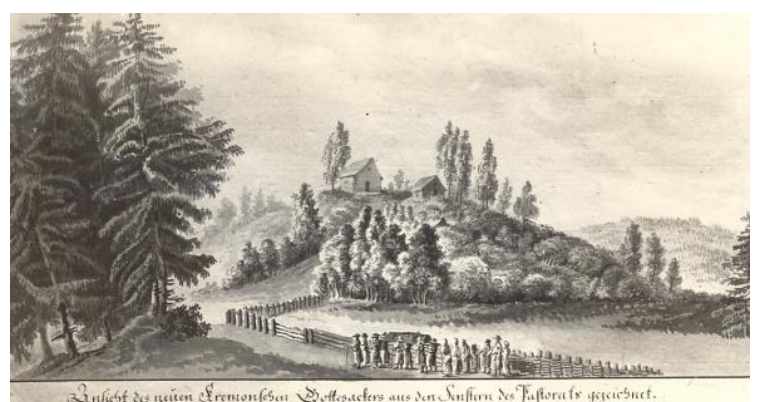

Fig. 13. The new cemetery of Krimulda, the sight from the pastorate [Source: Johann Christoph Brotze. Drawings and descriptions. Riga: Zinātne, 2002, Vol. 3, p. 172, 173]

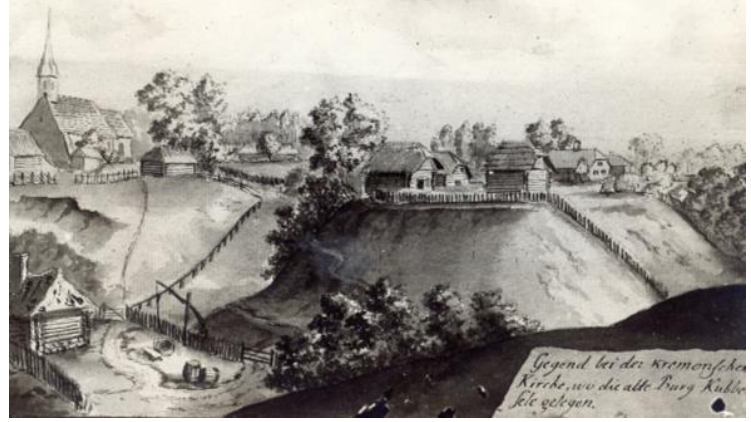

Fig. 14. The rectory and Krimulda Church

[Source: Johann Chistoph Brotze. Drawings and descriptions. Riga: Zinātne, 2002, Vol. 3, p. 166]

\section{The cultural and historical environment} and landscape

The immediate and furthest surroundings of the church are scenically appealing, intact of rashly considered structures and rich in historical evidence. The unique landscape of the church and the parsonage have impressed the coach and the local historian, the later professor of the University of Tartu - Johann Wilhelm Krause (J. E. Krause, 1757-1828), the drawing of whom was placed in the collection of drawings of J. Ch. Brotze [16]. The drawing is named according to the sentimental mood of the time of Romanticism - A sight of the new cemetery of Krimulda, drawn from the windows of the pastorate. At the end of the hill overgrown by trees and shrubs, two ancient mortuaries with a winding countryside road can be seen. The lovely landscape is made gloomy by a funeral procession which moves up the mound. The second drawing by J.V. Krause A sight to Krimulda Cemetery in 1796 is also dedicated to a similar theme. But this time, from the mound we look in the other direction - to the distant church and the rectory. Between the two fragmentarily depicted mortuaries, crosses and two small wooden buildings can be seen. And the third drawing: The neighborhood of Krimulda Church where the ancient Kubesele Castle was located belongs to J. V. Krause. It shows a vast landscape and from the aspect of the cultural and historical information, it provides a lot of interesting revelations. On the castle mound, the parsonage 


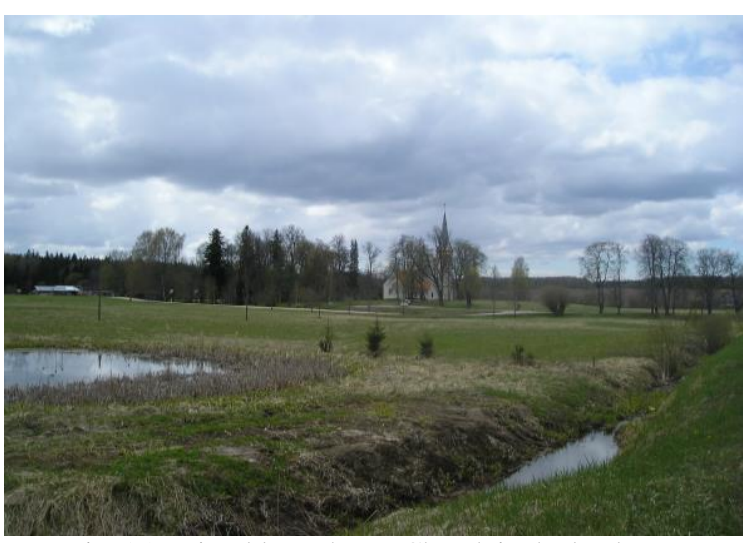

Fig. 15. Krimulda Lutheran Church in the landscape [Source: photo by author, 2017]

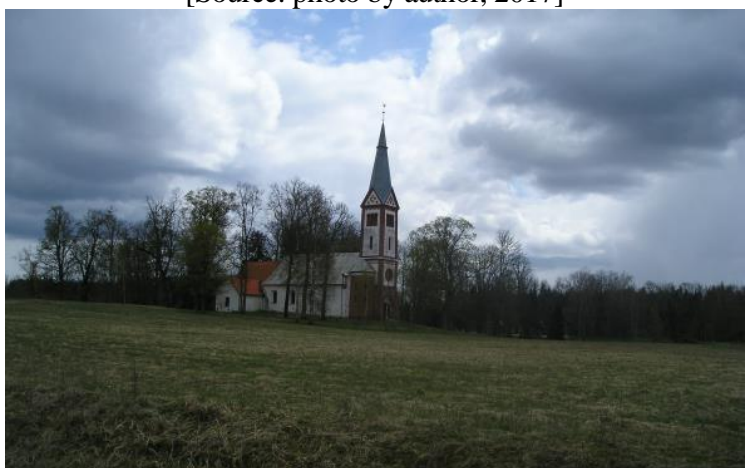

Fig. 16. Krimulda Lutheran Church in the landscape [Source: photo by author, 2017] buildings are located: three log houses in the front are meant for household purposes, behind them to the right there is the pastorate but between the church and the pastorate, there is also a small house. Also, in front of the church and at the foot of the hill buildings are depicted. In the drawing, the hillfort is easily perceptible that cannot be said today - its slopes are more overgrown.

\section{Conclusions}

Already from afar in the landscape, from the road Ragana - Turaida, surrounded by the tree canopy the church tower is still visible a significant vertical dominant. Other elements of the cultural and historical environment, as well as the rest of the building, is visible approaching them and they are of no interest in building a broad landscape of distant points of sight. And it is justified as the church is the main and most important building in the area.

In the course of time, a wide area around the church and the pastorate has retained its attractive landscape and its cultural and historical environment to a large extent - its authenticity. The conservation of this environment is a major challenge for the future.

\section{References}

1. Indriḳa hronika / Ā. Feldhūna tulkojums, Ē. Mugurēviča priekšvārds un komentāri. Rīga: Zinātne, 1993.

2. Caune, A., Ose, I. Latvijas viduslaiku müra baznīcas. 12. gs. beigas - 16. gs. sākums. Rīga: Latvijas vēstures institūta apgāds, 2010, 183. lpp.

3. Broce J.K. Zīmējumi un apraksti. Latvijas mazās pilsētas un lauki. Rīga: Zinātne, 2002, 3. sēj., 169. lpp.

4. Broce J.K. Ibid., 170. lpp.

5. Valsts kultūras pieminekḷu aizsardzības inspekcijas Pieminekḷu dokumentācijas centrs (VKPAI PDC), lieta Krimuldas luterānu baznīca.

6. VKPAI PDC, lieta Krimuldas luterāṇu baznīca.

7. VKPAI PDC, lieta Krimuldas luterānu baznīca.

8. Barkāns, E. Dievnams no Kaupo laikiem. Svētdienas rīts, 1996. gada 9. jūnijs.

9. Švalbe, J. Krimuldas dievnama zvanam - 100. Svētdienas rīts, 1995. gada 23. aprīlis.

10. Ermans, J. Krimuldas baznīca un draudze.1205-1930. Rīga: [B.i.], 1930, 5. lpp.

11. Ermans, J., ibid, 18. lpp.

12. Apīnis, A. Neprasot ațlauju. Latviešu rokraksta literatūra 18. un 19. gadsimtā. Rīga, 1987, 49.-51. lpp. Faksimilizdevums ar komentāriem: Juris Natanaēls Ramanis. Krusta skolas grāmata. Rīga: Zvaigzne ABC, 1995.

13. Latvijas valsts vēstures arhīvs (LVVA) F. 6828., descr. 6., p. 4430.

14. LVVA F. 1679., descr. 194., p. 86.

15. Jaksch, R. Bericht über Ausgrabungen in Kremon. Sitzungsberichte der Gesellschaft für Geschichte und Altertumskunde zu Riga. Jg. 1895, S. 118.-121.

16. Johans Kristofs Broce. Zīmējumi un apraksti. Latvijas mazās pilsētas un lauki. Rīga: Zinātne, 2002, 3. sēj., 172., 173. lpp.

INFORMATION ABOUT THE AUTHOR:

In 1979, Jānis Zilgalvis graduated from the Faculty of Architecture of the Riga Technical University. In 1990, he defended his doctoral thesis on the subject of the manor architecture of the second half of the $19^{\text {th }}$ century - the start of the $20^{\text {th }}$ century. Since then, he is the Head of the Architecture Department of the State Inspection for Cultural Monument Protection. Since 2012 - a full member of the Latvian Academy of Science. Over 180 scientific and popular scientific publications and 18 books (some coauthored). The main lines of research - the manor architecture and history of culture, sacral architecture, protection of cultural heritage. 
Kopsavilkums. Krimuldas baznīca ir pašreiz vecākā, vēl savam uzdevumam kalpojošā mūra baznīca Latvijā. Baznīcas mūžs ir notikumiem bagāts. Sākotnēji tā saukta par Kubeseles baznīcu un celta 1205.-1206. gadā priestera Alebranda vadībā, drīz pēc līvu valdnieka Kaupo atgriešanās no ceḷojuma uz Vāciju un Romu. Iespējams, ka viņa pīšli apglabāti Krimuldas baznīcas altārdaḷā. Baznīca vairākkārt remontēta un atjaunota (ap 1640. g., 1701., 1865.). Baznīca attēlota J. K. Broces 1794. gada zīmējumā. Jauns baznīcas tornis pabeigts 1905. gadā (arhitekts A. Reinbergs. Baznīca stipri cietusi 1917. un 1918. gadā - sašauts tornis, izsistas logu rūtis, izvazāti gandrīz visi baznīcas iekārtas priekšmeti. 2. Pasaules kara laikā dievnams necieta. 1960. gadā padomju varas spiediena rezultātā baznīca tika slēgta un draudze likvidēta. Sākās posta laiks. Draudze tika atjaunota 1988. gada nogalē. Draudzes priekšnieka K. Dimitera vadībā uzsākās dievnama atdzimšana. 1996. gadā ēka jau bija zem jumta, izbūvētas iekštelpas, sagādāti soli, vēlāk atjaunota kancele. Baznīcas tiešā tuvumā atrodas mācītājmuiža. Mācītājmāja ir savdabīgs koka arhitektūras klasicisma perioda paraugs. Tā pēc draudzes gana Jāṇa Ermana (Ērmaņa) ziṇām varētu būt celta Krimuldas muižas īpašnieka fon Helmersena ierosmē 1775. gadā. Mācītājmuižas apbūve kopā ar baznīcu veidoja plašas apkārtnes ainavisko un plānojuma struktūru. Par to var pārliecināties iepazīstoties ar 1821. gadā J. V. Krauzes zīmēto situācijas plānu, kurā detalizēti norādīta katra ēka, lielcel̦š, mežs un lauki, attālāk esošā kapsēta. Par situāciju ap dievnamu var spriest arī pēc Krimuldas pastorāta zemju plāna, kuru 1862. gadā zīmējis bruṇniecības revizors J. E. Vruks. Lejpus no pastorāta kalna pakājē atzīmēta skola, kas 1821. gada plānā nav uzrādīta.

Liela ir kultūrvēsturiskās vides daudzveidība baznīcas tiešā tuvumā. Tā ietver vēstures un arheologijas liecības, ainavas un dabas elementus. Pie mācītājmājas sākas 3.6 km garā Kubeseles dabas taka, kas izveidota 2002. gadā. Soḷojot pa to varam iepazīties ar virkni pieminekḷiem - Kubeseles pilskalnu, kurā 1991. gada arheoloǵiskās izpētes laikā atrasti agrā dzelzs laikmeta priekšmeti, Kaupo piemiñas vietu, kas iezīmēta ar piemiṇas akmeni. Vienā ceḷa posmā iespējams iepazīties ar baronu kapsētu, kura atrodas īpašā, 1820. gadā izveidotā Vecās kapsētas nodalījumā. Tajā atradās Englārtes jeb Engelhārtes muižas īpašnieka K. fon Dāla dzimtas kapi, kā arī grāfa Duntena kapliča. Par senvēsturi informāciju sniedz Batariṇu uzkalniņkapi, kuros guldīit tā dēvētie Gaujas zemgaḷi - baltu cilšu pārstāvji. Apbedījumi attiecas uz laiku no 1. gadu tūkstoša pirms Kristus dzimšanas līdz mūsu ēras pirmajiem gadsimtiem. Tie aprakstīti jau 19. gs. beigu publikācijās. Kapos vienā palielā uzkalninā laika gaitā guldīta vesela saime, pretēji lībiešu uzkalniṇkapiem, kuros katrā apbedīta tikai viena persona. Atceḷā, iepretim kalnā esošai mācītājmājai redzama Kubeseles ala, kas saukta arī par Runtinalu. Tā atgādina lielu istabu, kuras garums ir ap $6 \mathrm{~m}$, bet augstums ap $3 \mathrm{~m}$. Ala, kas ir aizsargājams ǵeoloǵisks objekts, izveidojusies augšdevona Gaujas svītas smilšakmeņos ilgstošas pazemes ūdeņu pārvietošanās rezultātā. Minētās vēstures, dabas un arheologijas liecības bagātina baznīcas tuvienes kultūrvēsturisko vidi, atspoguḷo gadsimtiem ilgās norises, kas veidojušās cilvēku un dabas vides mijiedarbībā. Ikviens no objektiem ir īpaši saudzējams un kopjams, respektējama ir to apkārtne jeb kultūrtelpa, bez kuras pilnvērtīga vēsturisko liecību uztvere nebūtu iespējama.

Ainaviski pievilcīga, nepārdomātu būvju neskarta un vēstures liecībām bagāta ir baznīcas tuvākā un tālākā apkārtne. Baznīcas un pastorāta apkārtnes neatkārtojamā ainava sajūsminājusi jau minēto J. V. Krauzi, kura zīmējumu savā krājumā ievietojis J. K. Broce. Kokiem un krūmiem apauguša pakalna galā redzamas divas senas kapličas, pie kurām vijas lauku ceḷš. Jauko ainavu padrūmu padara bēru procesija, kas virzas augšup kapu kalnā. Arī otrs J. V. Krauzes zīmējums Skats uz Krimuldas kapsētu 1796. gadā veltīts līdzīgai tematikai. Un arī trešais zīmējums Krimuldas baznīcas apkārtne, kur atradās senā Kubeseles pils pieder J. V. Krauzem. Tajā attēlota plaša ainava un no kultūrvēsturiskās izziņas aspekta tas sniedz daudz interesanta. Pilskalnā izvietotas pastorāta ēkas: priekšpusē trīs guḷbūves domātas saimnieciskām vajadzībām, aiz tām pa labi redzama pati mācītājmāja, bet starp baznīcu un pastorātu atrodas vēl kāda neliela ēciṇa.

Jau iztālēm ainavā, no ceḷa Ragana - Turaida, koku lapotņu ieskauts joprojām redzams baznīcas tornis nozīmīga vertikāla dominante. Pārējie kultūrvēsturiskās vides elementi, kā pārējā apbūve uztverami tiem tuvojoties un tiem nav nozīmes plašas ainavas veidošanā no tāliem skatu punktiem. Un tas ir pamatoti, jo dievnams bija centrālā un nozīmīgākā būve.

Plaša apkārtne ap baznīcu un mācītājmāju laika gaitā saglabājusi savu ainavisko pievilcību un tās kultūrvēsturiskā vide lielā mērā - autentiskumu. Šīs vides saglabāšana ir nozīmīgs nākotnes uzdevums. 